\title{
TOPONIMI GUNUNG SEMERU
}

\author{
Nabillah Djindan ${ }^{1}$ Multamia R. M. T. Lauder ${ }^{2}$ \\ ${ }^{12}$ Fakultas Ilmu Pengetahuan Budaya, Universitas Indonesia \\ Pos-el: Nabillah_d@yahoo.com
}

\begin{abstract}
Abstrak
Toponimi adalah ilmu yang mempunyai obyek studi tentang penamaan rupabumi. Unsur rupabumi yang menjadi perhatian dalam penelitian ini adalah Gunung Semeru (3.676 mdpl). Data diperoleh berdasarkan pemetaan ekspedisi sejak abad ke-19 untuk memperhatikan perubahan nama gunung, perkamusan untuk menelusuri makna nama gunung, dan data pendukung lain seperti tradisi lisan maupun sejarahHasil penelitian menunjukkan bahwa toponim Semeru sudah ada sejak abad ke-19 dalam peta ekspedisi Belanda. Pada temuan selanjutnya bahwa toponim Semeru pada proses semiosis pertama menandakan konsep budaya yang tertanam dalam pikiran masyarakat bahwa Gunung Semeru merupakan ancaman, proses semiosis kedua menandakan konsep budaya yang menamakan dataran tinggi dengan bahasa Jawa berdasarkan bentuknya, yaitu Gumuk, Redi, dan Wukir. Proses semiosis tersebut diturunkan lagi ke dalam dua interpretasi, yakni toponim Semeru yang berkaitan dengan agama.
\end{abstract}

Kata Kunci: etimologi, semeru, semiosis, toponimi

\begin{abstract}
Toponymy is the science that has the object of study about topographical naming. The topographical element of concern in this study is Mount Semeru (3,676 masl). Data is obtained based on expedition mapping since the 19th century to pay attention to changes in mountain names, forecasting to trace the meaning of mountain names, and other supporting data such as oral traditions and history. The results showed that Semeru toponym had been around since the 19th century on a map of the Dutch expedition. In subsequent findings that Semeru toponym in the first semiosis process signifies a cultural concept embedded in the mind of the community that Mount Semeru is a threat, the second semiosis process signifies a cultural concept that calls the plateau with Javanese based on its form, Gumuk, Redi, and Wukir. The semiosis process is reduced again into two interpretations, namely Semeru toponym which is related to religion.
\end{abstract}

Keywords: etymology, semeru, semiosis, toponymy 


\section{PENDAHULUAN}

Apalah arti sebuah gunung jika tanpa nama? Indonesia adalah negara kepulauan yang banyak sekali terdapat gunung, baik gunung berapi maupun bukan gunung berapi. Gunung-gunung tersebut tersebar di pulau-pulau Indonesia dengan rentang ketinggian mulai dari 1.000 hingga 4.000 meter dari permukaan laut (Agustin, 2015 : 2). Finch dan Trewartha (1949) dalam Barry (2008 : 2) mendefinisikan bahwa yang masuk dalam kriteria pegunungan adalah pada ketinggian 1.800 meter dari permukaan laut (mdpl). Gunung Semeru merupakan tipe gunungapi strato dengan kubah lava mencapai ketinggian 3.744,50 mdpl. Adapun nama lain dari Semeru adalah Semeroe, Smeru, dan Smiru.

Ejaan nama tersebut dibuktikan dengan adanya temuan peta ekspedisi dari Belanda pada abad ke-19, yaitu peta Beschryving van de vulkanen Semeroe en Lemongan dengan nama peta Top van den Semeroe tahun 1879 yang menuliskan "Semeroe" sebagai nama gunung dan "Mahameroe" sebagai nama puncak yang tidak pernah terpisahkan dalam penulisan peta hingga pada abad sekarang ini. Perbedaan yang terjadi sejauh ini bahwa toponimi gunung masih jarang ditemukan untuk membahas masalah pemaknaan nama gunung yang nampak tidak terlalu penting, padahal setiap gunung sudah memiliki nama begitu juga dengan Gunung Semeru selalu berkaitan erat dengan Mahameru sebagai nama puncak tertingginya. Karena penelitian ini berkaitan dengan nama gunung, maka dijelaskan secara terminologi oleh Rais et al (2008 : 78) mengenai Oronym (Oronim), yaitu nama yang diterapkan pada unsur yang berelevasi, seperti bukit dan gunung disebut sebagai oronim. Sama halnya penelitian yang dilakukan oleh Drummond dalam Hough (2016 : 118) yang membahas tentang oronim generik bahwa oronim terdiri dari elemen seperti bukit, gunung, dan sebagainya. Oronim merupakan bagian dari onomastik yang dijelaskan oleh Lauder (2015 : 384), bahwa studi disiplin ilmu penamaan disebut juga sebagai onomastik (onomatologi), merupakan cabang ilmu linguistik yang disebut linguistik historis komparatif dan onomastik fokus kepada asal-usul kata atau etimologi dan juga makna di balik nama.

Kajian nama tempat atau toponimi di Indonesia saat ini semakin mendapat perhatian. Toponimi dalam bahasa Inggris "toponym" secara harafiah artinya nama tempat di muka bumi dan dalam bahasa Inggris kadang-kadang disebut "geographical names" (nama geografis) atau "place names". Dalam bahasa Indonesia kita pakai istilah "nama unsur geografi" atau "nama geografis" atau "nama rupabumi". 
Rupabumi adalah istilah bahasa Indonesia untuk “topografi”. Dalam UU No. 32 Tahun 2004 tentang Pemerintahan Daerah di pasal 7 disebut "nama bagian rupabumi" (topografi) atau nama "unsur rupabumi". Begitu juga dalam Peraturan Presiden No. 112 Tahun 2006 tentang Tim Nasional Pembakuan Nama Rupabumi, dipakai istilah “nama rupabumi” (Rais et al, 2008 : 4-5).

Penelitian ini berlandaskan Toponimi, yaitu ilmu yang mempelajari nama unsur rupabumi atau totalitas dari topinim dalam suatu wilayah atau region (Rais et al, 2008 : 88), ditelusuri berdasarkan Linguistik yang mendatangkan arti secara Etimologi. Durkin (2009 : 1-2) mengatakan bahwa etimologi adalah investigasi sejarah kata, penyebaran bahasanya, dan asal mula sebuah kata yang merupakan bagian dari bidang penelitian linguistik historis. Etimologi dalam penelitian toponimi ini tidak lepas dari penelusuran peta ekspedisi dalam menjabarkan periode munculnya namanama gunung, serta melihat adanya perubahan bentuk, bunyi, maupun makna denotasi yang ada dalam perkamusan. Penelitian dilanjutkan dengan menelusuri tradisi lisan maupun sejarah yang digunakan untuk perkembangan makna Konotasi dari mitos Barthes dalam Hoed (2011) melalui wawancara pada narasumber dan fokus utama yang terpenting adalah melihat berbagai gejala dalam suatu kebudayaan sebagai tanda yang dimaknai oleh masyarakat melalui kajian Semiotik Peirce. Berdasarkan penjelasan tersebut, maka penelitian ini akan menelusuri bagaimana asal mula terbentuknya nama Gunung Semeru dan bagaimana masyarakat memaknai nama Gunung Semeru.

\section{METODE PENELITIAN}

Sudaryanto (2015: 201-203) memaparkan beberapa teknik pengumpulan data dalam bukunya yang berjudul "Metode dan Aneka Teknik Analisis Bahasa" di mana Sudaryanto menggunakan istilah "penyediaan data". Penyediaan data adalah penyediaan data yang benar-benar data, penyediaan data yang terjamin sepenuhnya akan kesahihannya, penyediaan data yang sangat patut atau sangat pantas untuk dipercaya kualitas kedataannya. Dalam hal ini, metode penyedian data dikenal pada prinsipnya ada dua saja, yaitu "metode simak" dan "metode cakap"; dan tekniknya pun sebagai penjabaran dibedakan atas dua macam berdasarkan tahap pemakaiannya, yaitu "teknik dasar" dan "teknik lanjutan". Disebut metode simak atau penyimakan karena memang berupa penyimakan atau dilakukan dengan menyimak, yaitu menyimak pengguna bahasa. Ini dapat disejajarkan dengan "metode pengamatan" atau "observasi" dalam ilmu sosial. Teknik dasar yang meliputi "teknik sadap" pada 
praktiknya si peneliti untuk mendapatkan data, pertama-tama dengan segenap kecerdikan dan kemauannya harus menyadap pembicaraan seseorang atau beberapa orang. Teknik lanjutan terbagi atas empat bagian.

1) Teknik lanjutan I meliputi "teknik simak libat cakap", pada saat kegiatan menyadap itu dilakukan pertama-tama dengan berpartisipasi sambil menyimak dalam pembicaraan. Jadi, peneliti terlibat langsung dalam dialog sambil memperhatikan penggunaan bahasa mitra wicaranya.

2) Teknik lanjutan II meliputi "teknik simak bebas libat cakap", peneliti tidak bertindak sebagai pembicara yang berhadapan dengan mitra-wicara. Peneliti hanya sebagai pemerhati yang penuh minat tekun mendengarkan apa yang dikatakan (dan bukan apa yang dibicarakan) oleh orang-orang yang hanyut dalam proses dialog. Dengan kata lain teknik ini ikut menentukan pembentukan dan pemunculan calon data dari peristiwa kebahasaan yang berada di luar dirinya.

3) Teknik lanjutan III meliputi "teknik rekam", ketika teknik pertama dan kedua digunakan sekaligus, maka dapat dilakukan pula perekaman dengan tape atau voice recorder tertentu sebagai alatnya.
4) Teknik lanjutan IV meliputi "teknik catat", selain merekam dilakukan pula pencatatan pada kartu data yang segera dilanjutkan dengan klarifikasi. Pencatatan tersebut dapat dilakukan langsung ketika teknik pertama atau kedua selesai digunakan atau sesudah perekaman dilakukan (Sudaryanto, 2015: 203-206).

Sementara itu, Lauder (1990 : 66-67) menambahkan bahwa pengumpulan data menggunakan metode penelitian lapangan dengan pertimbangan bahwa peneliti dapat secara langsung memperhatikan, mendengar, mencatat, merekam, dan mengumpulkan keterangan-keterangan lain yang tidak tercatat dalam panduan wawancara dan diperkirakan dapat melengkapi bahan. Hal-hal yang bertalian dengan adat-istiadat, keadaan sosial budaya, dan lingkungan daerah penelitian akan dapat diamati dengan lebih baik.

Karena penelitian ini merupakan penelitian toponimi, maka dipaparkan pula contoh pengambilan data sebagai acuan yang dilakukan oleh Sulistiyo (2008: 141142; Rais et al, 2008: 129-152) menjelaskan dalam artikelnya yang berjudul Survei Toponimi Pulau-Pulau Di Indonesia bahwa wawancara dilakukan sebagai upaya dalam pengisian formulir nama pulau. Responden atau orang yang diwawancarai dalam survei Toponim Pulau-pulau dibedakan menjadi: 
1) Wawancara dengan Penduduk

Penduduk yang dimaksud dengan pengertian ini adalah anggota masyarakat atau kelompok masyarakat yang tinggal di pulau atau secara rutin melakukan aktivitas di lokasi yang disurvei.

2) Wawancara dengan Tokoh Masyarakat

Tokoh masyarakat dalam hal ini adalah pejabat daerah setempat atau orang yang dituakan. Wawancara disamping untuk mendapatkan informasi tentang nama, juga dititikberatkan untuk mendapatkan informasi penting lainnya. Saat wawancara dilakukan, petugas harus selalu menyimak secara seksama dan mendokumentasikan secara baik. Mengingat informasi yang diterima dalam waktu yang singkat cukup banyak, maka dokumentasi hasil wawancara selain ditulis dalam buku catatan, juga direkam dengan alat perekam. Berdasarkan data ini, selanjutnya peneliti dapat mengungkap faktor-faktor perubahan penamaan.

\section{3) Pemilihan Titik Pengamatan}

Pemilihan titik pengamatan yang sesuai dengan cakupan di atas telah dilakukan sebelum turun ke lapangan dan sebagian lagi baru dilakukan setelah mendapatkan informasi dari informan di lapangan. Sebelum turun ke lapangan peneliti telah mendapat informasi dari ahli toponimi
Jakarta, yaitu Prof. Dr. Multamia M.R.T. Lauder, M.Sc., DEA. yang merupakan salah satu pakar toponimi di Indonesia. Penelitian ini berlokasi di kawasan Taman Nasional Bromo Tengger Semeru yang terletak di 4 (empat) Kabupaten, yaitu Kab. Probolinggo, Kab. Malang, Kab. Pasuruan, dan Kab. Lumajang.

\section{HASIL DAN PEMBAHASAN}

Ketinggian Semeru mencapai 3.676 meter dan permukaan laut. Sosok puncak gunung ini juga dikenal dengan "Mahameru". Pada puncak gunung terdapat sebuah kawah yang dikenal dengan sebutan "Jonggring Seloka". Gunung ini berada di Jawa Timur, tepatnya di kompleks dataran tinggi Tengger. Secara administrasi berada di wilayah Malang dan Lumajang pada posisi geografis $8^{\circ} 06.5^{\prime} \mathrm{LS}$ dan $112^{\circ} 55^{\prime}$ BT. Gunung Semeru merupakan gunung berapi tertinggi ketiga Indonesia dan dari kejauhan Semeru menunjukkan bentuk kerucut yang sempurna. Namun, saat berada di puncak, kerucut tersebut nampak seperti kubah yang luas di setiap tebingnya (Agustin, $2015:$ 32-33). 


\section{Penelusuran Gunung Semeru}

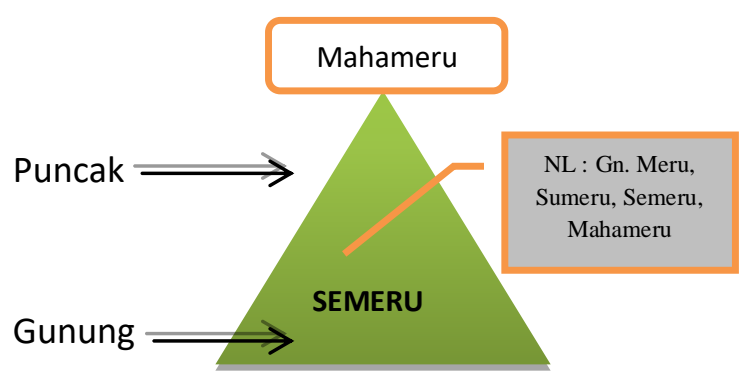

Gambar 4. Nama lain dan Puncak Gunung Semeru

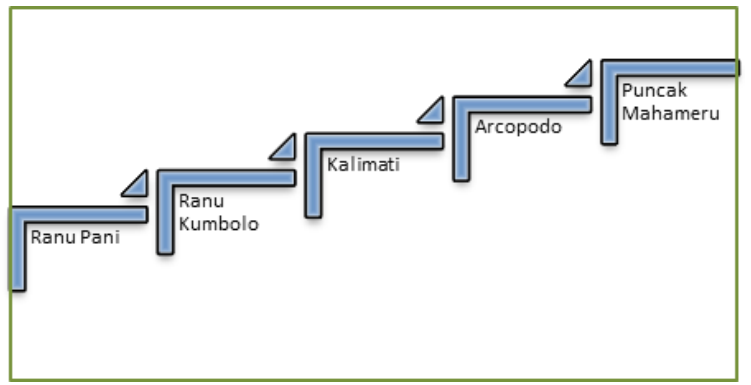

Gambar 5. Nama-nama Jalur Pendakian

Menurut kepercayaan masyarakat Jawa seperti yang tertuang pada kitab kuno bernama "Tantu Panggelaran" yang dipercaya berasal pada abad ke-15, dituliskan bahwa suatu ketika Pulau Jawa mengambang di tengah laut dan dipermainkan ombak. Kemudian, para dewa memutuskan untuk memakunya supaya tidak bergerak dengan cara memindahkan Gunung Meru yang berada di India ke Jawa. Di sana dipercaya asal mula nama Mahameru diperoleh. Bagi orang Bali, Gunung Semeru atau Mahameru dipercaya sebagai bapak Gunung Agung di Bali dan sangat dihormati. Upacara sesaji untuk menghormati dewa-dewa di Mahameru sering dilakukan oleh masyarakat Bali. Walaupun upacara penghormatan tersebut hanya dilakukan setiap 8-12 tahun sekali pada waktu orang menerima suara gaib dari dewa Mahameru. Selain itu, orang Bali sering mengunjungi Gua Widodaren untuk mendapatkan "Tirta Suci” (Agustin, 2015: 41).

\section{Etimologi Gunung Semeru}

1) Sumber: Sanskrit in Indonesia, Dr. J. Gonda, 1973

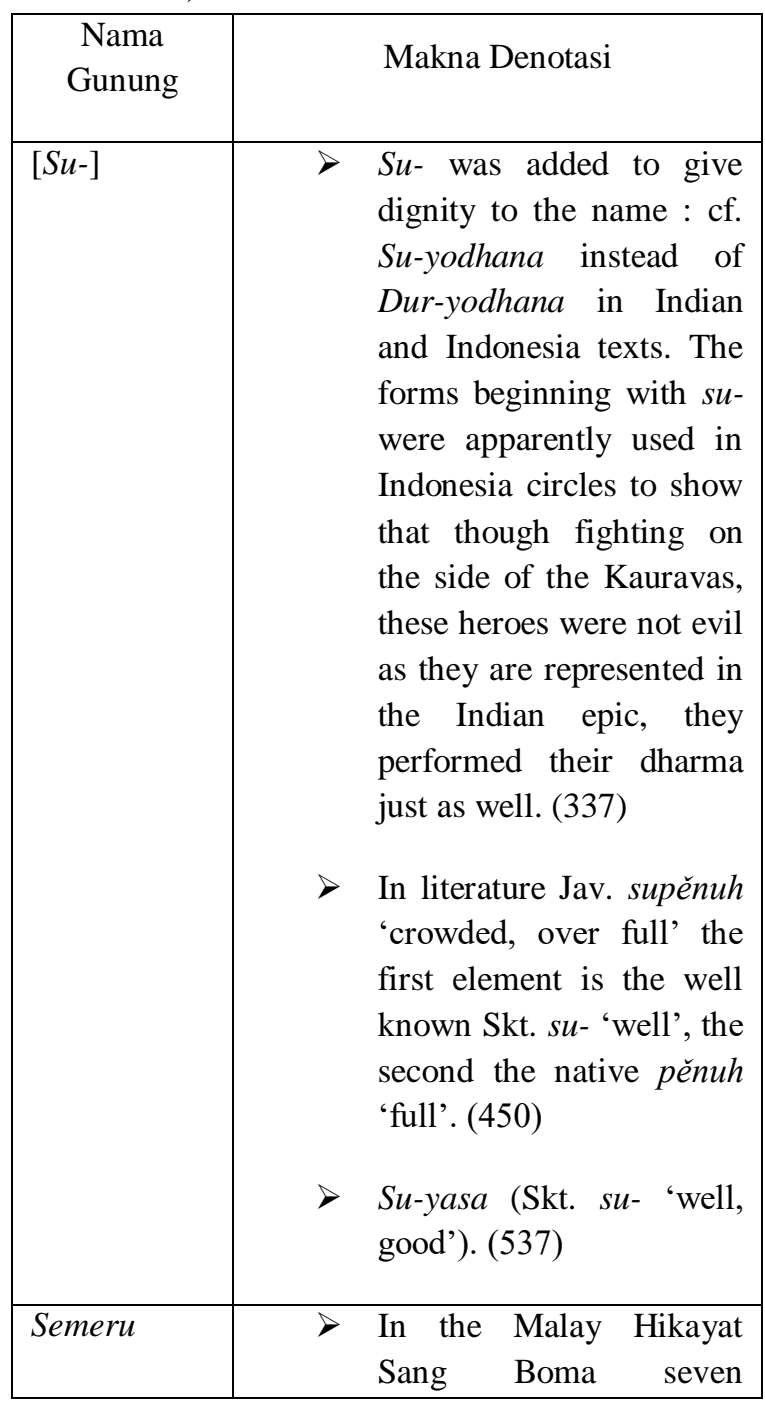




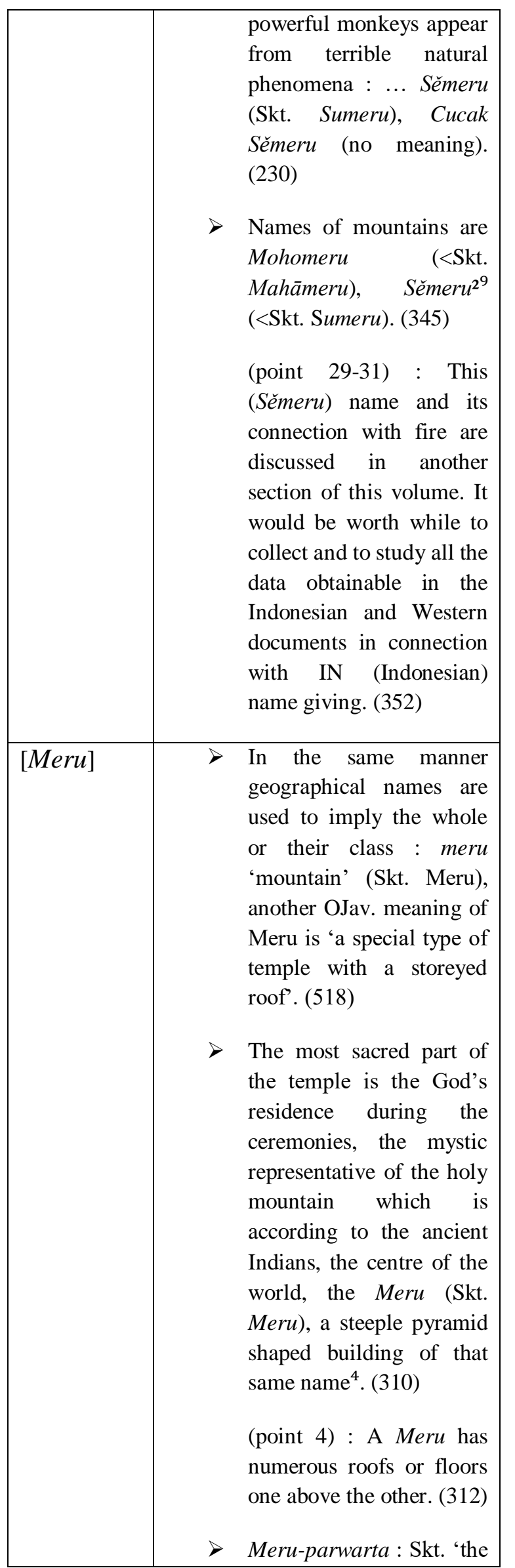

\begin{tabular}{|l|l|}
\hline & Meru Mountain'. (457) \\
In the same manner \\
geographical names are \\
used to imply the whole \\
or their class : lit. Java \\
Meru 'mountain' (Skt. \\
Meru), another OJav. \\
meaning of meru is a \\
special type of temple \\
with a storeyed roof'. \\
(518) \\
The ameliorative element \\
su- was already in \\
Sanskrit affixed to such \\
words as Meru 'the \\
central mount Meru' > \\
Sumeru 'id.' which was \\
introduce into Javanese. \\
(552)
\end{tabular}

2) Sumber: Sanskrit in Indonesia, Dr. J. Gonda, 1973.

\begin{tabular}{|c|c|c|}
\hline $\begin{array}{c}\text { Nama } \\
\text { Puncak }\end{array}$ & & Makna Denotasi \\
\hline [Maha- $]$ & $\begin{array}{l}> \\
\\
>\end{array}$ & $\begin{array}{l}\text { The use of Skt. mahā } \\
\text { 'great' which also occurs in } \\
\text { such loan words as Jav. } \\
\text { Mal. Etc. maharaja '(great) } \\
\text { prince, very royal' < Skt. } \\
\text { mahārāja 'supreme king'. } \\
\text { (448) } \\
\text { Mahā-śaktimān 'very } \\
\text { powerful' ; mahāsāra } \\
\text { 'name of a musical'. (477) }\end{array}$ \\
\hline Mahameru & $\begin{array}{l}D \\
D \\
D\end{array}$ & $\begin{array}{l}\text { In the first } 14 \text { lines (98 } \\
\text { words) of the Tantu } \\
\text { Panggělaran we find } 23 \\
\text { Sanskrit words; } \\
\text { Mahāmeru 'the great } \\
\text { (mountain) Meru'. (204) } \\
\text { Mahameru (Skt. Mahāmeru } \\
\text { 'the great central } \\
\text { mountain'). (229) } \\
\text { The mountain to which the } \\
\text { founder of Malay royalty } \\
\text { came down was afterwards } \\
\text { called Mahameru (Skt. } \\
\text { Mahāmeru 'the legendary } \\
\text { central mountain of Hindu }\end{array}$ \\
\hline
\end{tabular}




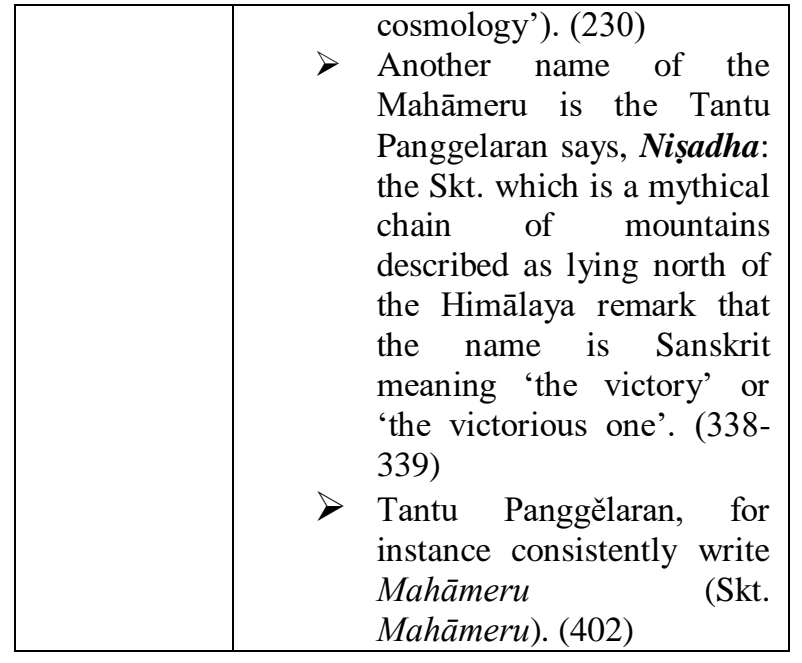

3) Sumber: Baoesastra Djawa, W.J.S. Poerwadarminta, 1939

\begin{tabular}{|c|c|}
\hline $\begin{array}{c}\text { Nama } \\
\text { Gunung }\end{array}$ & Makna Denotasi \\
\hline$[$ Mèroe $]$ & goenoeng (303) \\
\hline
\end{tabular}

4) Sumber: Kamus Istilah Arkeologi Cagar Budaya, R. Cecep Eka Permana, 2016

\begin{tabular}{|c|l|}
\hline \multicolumn{1}{|c|}{ Namang } & Makna Denotasi \\
\hline [Meru] & Bangunan meru \\
& merepresentasikan Gunung \\
& Mahameru, berbentuk \\
& makin ke atas makin \\
& mengecil dan atapnya terdiri \\
& dari atap tumpang atau \\
& selalu memiliki atap yang \\
& bertingkat-tingkat (jumlah \\
& atap umumnya ganjil dari \\
& tiga sampai sebelas) terbuat \\
& dari ijuk. \\
\hline
\end{tabular}

5) Sumber: Kamus Kawi-Indonesia, Wojowasito, 1977

\begin{tabular}{|c|cl|}
\hline $\begin{array}{c}\text { Nama } \\
\text { Gunung }\end{array}$ & & \multicolumn{1}{c|}{ Makna Denotasi } \\
\hline$[$ Meru $]$ & $>$ & nama gunung (170) \\
Sameru & $>$ & sebesar gunung Meru (170) \\
Meruparwata & $>$ & gunung Meru (170) \\
Merutulya & $>$ & laksana gunung Meru (170) \\
\hline
\end{tabular}

6) Sumber: Kamus Lengkap JawaIndonesia, Sutrisno Utomo, 2009

\begin{tabular}{|c|c|}
\hline $\begin{array}{c}\text { Nama } \\
\text { Gunung }\end{array}$ & Makna Denotasi \\
\hline$[$ Méru $]$ & $\begin{array}{l}\text { gunung - pancake }: \text { tempat } \\
\text { pembakaran jenazah }(246)\end{array}$ \\
\hline
\end{tabular}

7) Sumber: Kamus Besar Bahasa Indonesia, Tim Penyusun Kamus Pusat Pembinaan dan Pengembangan Bahasa, 1990

\begin{tabular}{|c|l|}
\hline \multicolumn{1}{|c|}{$\begin{array}{c}\text { Nama } \\
\text { Gunung }\end{array}$} & \multicolumn{1}{c|}{ Makna Denotasi } \\
\hline [Meru/Méru] & $\begin{array}{l}\text { 1 gunung di mitologi Hindu } \\
\text { tempat persemayam para dewa } \\
\text { dan makhluk kedewaan, serta } \\
\text { menjadi pusat jagat raya ; 2 Ragam } \\
\text { hias berbentuk segitiga sebagai } \\
\text { lambang persemayam dewa ; 3 } \\
\text { bangunan yang terdapat di kuil } \\
\text { yang merupakan tempat } \\
\text { persembahan yang terdiri atas tiga } \\
\text { sampai sebelas atap atau tingkat } \\
\text { (di Bali) (578) }\end{array}$ \\
\hline
\end{tabular}

Berdasarkan tabel di atas pada temuan berdasarkan perkamusan, dapat dilihat bahwa nama gunung Semeru terdiri dari beberapa leksem, [meru], [maha], [mahameru], dan [semeru] di mana Semeru merupakan nama gunung, sedangkan Mahameru merupakan nama puncak gunung. Secara etimologi Semeru memiliki arti yang sempit, yaitu istilah yang disebutkan dalam kamus Sanskrit in Indonesia bahwa Semeru merupakan sebuah istilah nama tempat yang muncul dalam hikayat melayu Sang Boma yang mengisahkan tentang tujuh kekuatan kera 
yang berasal dari fenomena alam yang buruk. Berbeda dengan pengertian Mahameru dalam bahasa Sanskrit yang berarti gunung terbesar sebagai pusat persemayam para dewa.

\section{Tahapan Perkembangan Morfologis dan Bunyi Nama G. Semeru}

\begin{tabular}{|c|c|c|c|}
\hline Sumber & Abad 19 & Abad 20 & $\begin{array}{c}\text { Abad } \\
21\end{array}$ \\
\hline & $>1809$ & $>1909$ & $>2009$ \\
\hline $\begin{array}{l}\text { L1 - } \\
1879 \text { - } \\
\text { SMR }\end{array}$ & $\begin{array}{l}\text { semeroe }^{\mathrm{G}} \\
\text { [səmeru] }\end{array}$ & & $\begin{array}{l}\text { mahameroe }^{\mathrm{P}} \\
{[\text { mahaməru }]}\end{array}$ \\
\hline $\begin{array}{l}\text { L1 - } \\
1885 \text { - } \\
\text { SMR }\end{array}$ & $\begin{array}{l}\text { semeroe }^{\mathrm{G}} \\
\text { [səmeru] }\end{array}$ & & $\begin{array}{l}\text { mahameroe }^{\mathrm{P}} \\
{[\text { mahaməru }]}\end{array}$ \\
\hline $\begin{array}{l}\text { L1 - } \\
1886 \text { - } \\
\text { SMR }\end{array}$ & $\begin{array}{l}\text { semeroe }^{G} \\
\text { [səmeru] }\end{array}$ & & \\
\hline $\begin{array}{l}\text { L1 - } \\
1909 \text { - } \\
\text { SMR }\end{array}$ & & $\begin{array}{l}\text { semeroe }^{\mathrm{G}} \\
\text { [səmeru] }\end{array}$ & $\begin{array}{l}\text { mahameroe }^{\mathrm{P}} \\
{[\text { mahaməru }]}\end{array}$ \\
\hline $\begin{array}{l}\text { L1 - } \\
1915- \\
1922- \\
\text { SMR }\end{array}$ & & $\begin{array}{l}\text { semeroe }^{\mathrm{G}} \\
{[\text { səmeru] }}\end{array}$ & $\begin{array}{l}\text { mahameroe }^{\mathrm{P}} \\
{[\text { mahaməru }]}\end{array}$ \\
\hline $\begin{array}{l}\text { L1 - } \\
1926- \\
\text { SMR }\end{array}$ & & $\begin{array}{l}\text { semeroe }^{\mathrm{G}} \\
\text { [səmeru] }\end{array}$ & \\
\hline $\begin{array}{l}\text { L1 - } \\
1926 \text { - } \\
\text { SMR }\end{array}$ & & $\begin{array}{l}\text { mahameroe }^{\mathrm{G}} \\
{[\text { mahaməru] }}\end{array}$ & \\
\hline $\begin{array}{l}\text { L1 - } \\
1943- \\
1944- \\
\text { SMR }\end{array}$ & & $\begin{array}{l}\text { semeroe }^{\mathrm{G}} \\
\text { [səmeru] }\end{array}$ & $\begin{array}{l}\text { mahameru }^{\mathrm{P}} \\
{[\text { mahaməru] }}\end{array}$ \\
\hline $\begin{array}{l}\text { L1 - } \\
1943- \\
1945 \text { - } \\
\text { SMR }\end{array}$ & & $\begin{array}{l}\text { mahameru }^{\mathrm{G}} \\
{[\text { mahaməru] }}\end{array}$ & \\
\hline $\begin{array}{l}\text { L1 - } \\
1963- \\
\text { SMR }\end{array}$ & & $\begin{array}{c}\text { Semeru } \\
\text { [səmeru] }\end{array}$ & $\begin{array}{l}\text { mahameru }^{\mathrm{P}} \\
{[\text { mahaməru] }}\end{array}$ \\
\hline $\begin{array}{l}\text { L1 - } \\
1992- \\
\text { SMR }\end{array}$ & & $\begin{array}{l}\text { mahameru } \\
\text { [mahaməru] }\end{array}$ & \\
\hline $\begin{array}{l}\text { L1 - } \\
1995 \text { - } \\
\text { SMR }\end{array}$ & & $\begin{array}{l}\text { mahameru }^{\mathrm{G}} \\
{[\text { mahaməru] }}\end{array}$ & \\
\hline Ket. & $=$ Nama O & $\begin{array}{c}\text { ang, } \mathrm{G}=\text { Nam } \\
\text { Puncak }\end{array}$ & Gunung, $\mathrm{P}=$ Nama \\
\hline
\end{tabular}

Berdasarkan temuan peta ekspedisi, tabel di atas dapat dilihat bahwa pada abad ke-19 pada toponim gunung Semeru masih menggunakan tulisan ejaan lama, seperti pada fonem vocal /oel yang melekat pada fonem konsonan $/ r /$, yaitu [semeroe] dan sama halnya yang terjadi pada nama puncaknya, yaitu [mahameroe]. Memasuki abad ke-20, yaitu pada tahun 1909 sampai dengan tahun 1926 masih konsisten menuliskan [semeroe] atau belum ada perubahan tulisan ejaan lama, begitu pula dengan nama puncaknya. Penulisan toponim pada tahun 1943 sampai dengan 1995 sudah mengikuti tulisan ejaan baru, yaitu [semeru] dan nama puncak [mahameru]. Toponim gunung maupun puncak ini dari abad ke abad sangat konsisten, hanya terjadi perbedaan penulisan ejaan terhadap bunyi yang tidak mempengaruhi perubahan bentuk leksem.

\section{Metabahasa Konotasi}

Penguraian mitos dapat terlihat dengan menelusuri pergeseran makna denotasi ke makna konotasi. Namun untuk mendapatkan hasil sementara, peneliti belum menggunakan tradisi lisan sebagai data primer, melainkan penelitian ini menganalisis berdasarkan data sekunder dari perkamusan yang telah diuraikan pada tabel 5.1.1 dan data pendukung lainnya untuk melihat perubahan makna konotasi, seperti : 
(1) buku "Latar Belakang Sosial Budaya dan Historik Orang Tengger Lumajang dan Gunung Semeru” dalam penelitian Sutarto (1997); (2) “Tantu Panggelaran (Representasi Ruang Simbolik dalam Konsep Kesempurnaan Dunia Jawa) dalam penelitian Setyani (2011); (3) buku "Gunung, Bencana, dan Mitos di Nusantara" oleh Herliany dkk (2015); dan (4) penelitian "Kajian Mitos dan Nilai Budaya dalam Tantu Panggelaran" oleh Nurhajarini dan Suyami (1999). Maka, untuk mendapatkan hasil yang lebih maksimal perlu adanya tinjauan lebih lanjut untuk penelitian lapangan agar mendapatkan data tradisi lisan maupun sejarah yang hidup dalam masyarakat.

Berdasarkan data sekunder yang telah diuraikan, maka perkembangan kata Semeru dapat dijelaskan dengan teori metabahasa konotasi Barthes. Pemaknaan baru menandakan adanya pengembangan isi [C], sedangkan pembentukan kata baru menandakan pengembangan ekspresi [E]. Berdasarkan makna denotasi, Semeru awalnya merupakan gunung suci tempat persemayam para dewa [C1]. Gunung ini merupakan tanda, kemudian makna tanda ini mengalami konotasi menjadi tanda tempat pembakaran jenazah dan bangunan Meru (memiliki atap bertingkat yang terdiri dari tiga sampai sebelas atap) yang merepresentasikan puncak Mahameru [E2].
Bagan Metabahasa dan Konotasi Gunung Semeru

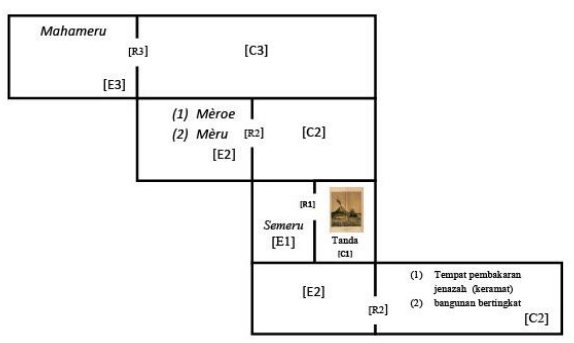

\section{Semiotik}

Dalam penelitian ini peneliti menggunakan teori analisis semiotika Charles Sanders Peirce yakni melalui proses semiosis yang terdiri dari tiga tahapan penandaan. Mulai dari representamen (tanda), object (sesuatu yang lain) dan interpretant (proses penafsiran). Berikut ini merupakan contoh analisis semiosis Peirce yang diterapkan pada Gunung Semeru:

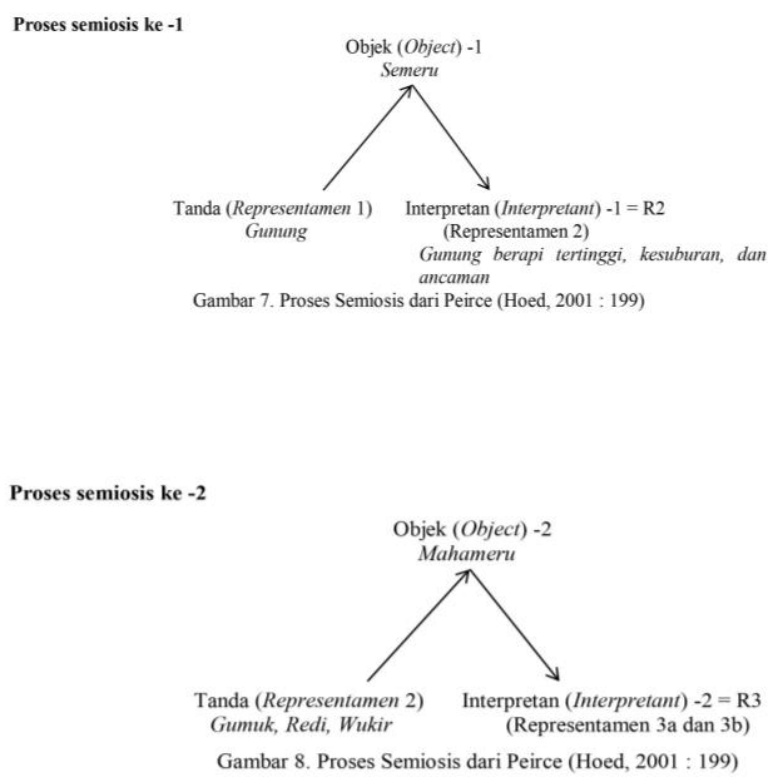




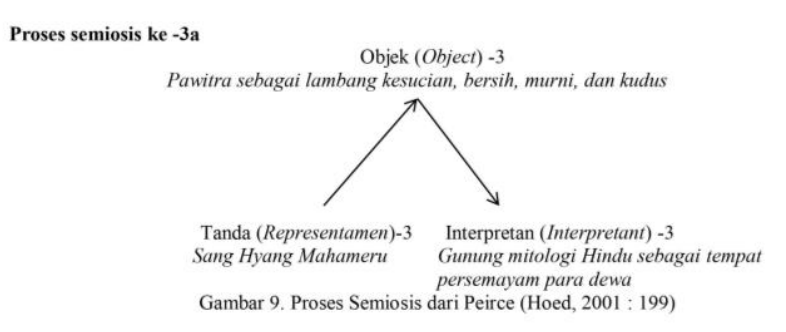

Proses semiosis ke - -3b

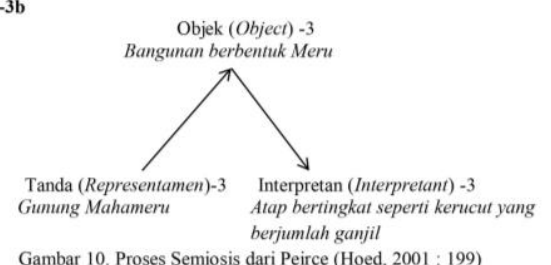

Hasil interpretasi data sementara yang telah ditemukan peneliti dapat diuraikan dalam penjelasan sebagai berikut :

1) Pada proses semiosis ke -1 merepresentasikan Gunung sebagai Semeru yang merupakan nama gunung berwujud sebesar gunung Meru dimaknai sebagai gunung berapi tertinggi di tanah Jawa yang bisa saja mendatangkan bencana, namun di lain sisi gunung ini memberikan keuntungan bagi masyarakat lokal dalam lingkup pertanian dengan kadar tanah yang subur.

2) Pada proses semiosis ke -2 merepresentasikan Gumuk, Redi, dan Wukir sebagai Mahameru yang merupakan nama puncak tertinggi yang terbagi menjadi dua makna, yaitu representasi proses semiosis ke -3a dan $3 b$.

3) Pada proses semiosis ke $-3 a$ merepresentasikan Sang Hyang Mahameru sebagai nama lain dari Pawitra sebagai kesempurnaan diri yang tercermin antara alam semestamanusia-Tuhan yang suci, bersih, murni, dan kudus sehingga dimaknai sebagai gunung mitologi Hindu yang merupakan tempat persemayam para dewa dan puncaknya terletak kota para Dewa, serta di atasnya terletak menara sebagai tempat surgawi.

4) Pada proses semiosis ke $-3 b$ merepresentasikan Gunung Mahameru sebagai bentuk bangunan dimaknai sebagai wujudnya yang semakin ke atas semakin mengecil dan atapnya terdiri dari atap tumpang yang selalu memiliki atap bertingkat-tingkat (jumlah atap umumnya ganjil dari tiga sampai sebelas).

\section{SIMPULAN}

Berdasarkan hasil analisis yang telah dilakukan, mulai dengan memperhatikan pembahasan analisis perubahan bentuk dan bunyi, pergeseran makna konotasi, kemudian sampai pada tahap analisis proses semiosis Peirce berdasarkan temuan data pendukung, seperti peta ekspedisi, perkamusan dan catatan literatur dalam 
penelitian kebudayaan. Maka, peneliti menyimpulkan toponim gunung Semeru dan puncak Mahameru dapat diuraikan sebagai berikut :

1) Toponim Semeru sudah muncul sejak pada abad ke-19, yaitu pada tahun 1879 pada peta ekspedisi Belanda.

2) Toponim gunung maupun puncak ini dari abad ke abad sangat konsisten, hanya terjadi perbedaan penulisan ejaan terhadap bunyi yang tidak mempengaruhi perubahan bentuk leksem, sedangkan bahasa yang melatarbelakangi nama gunung maupun puncak ini dominan dari bahasa Sanskrit dan Jawa Kuna (Old Java) berdasarkan informasi dominan yang ditunjukkan dalam kamus Sanskrit in Indonesia.

3) Toponim Semeru pada proses semiosis pertama menandakan konsep budaya yang tertanam dalam pikiran masyarakat bahwa Gunung Semeru merupakan ancaman yang jika tiba pada waktunya (erupsi) akan mendatangkan musibah. Proses semiosis kedua menandakan konsep budaya yang menamakan dataran tinggi dengan bahasa Jawa berdasarkan bentuknya, yaitu Gumuk, Redi, dan Wukir. Selain berdasarkan bentuk tempatnya yang menjulang tinggi ke atas, proses semiosis ini diturunkan lagi ke dalam dua interpretasi yang menjadi satu kesimpulan akhir, yakni toponim Semeru yang berkaitan dengan agama.

\section{DAFTAR PUSTAKA}

Agustin, Hendri. (2015). The Seven Summits of Indonesia. Yogyakarta: CV. Andi Offset.

Barry, G. R. (2008). Mountain Weather and Climate. UK: Cambridge University Press.

Durkin, Philip. (2009). "The Etymology of Names", in: Philip Durkin, The Oxford Guide to Etymology, pp. 266-283. Oxford : Oxford University Press.

Durkin, Philip. (2009). The Oxford Guide to Etymology. Oxford: Oxford University Press.

Drummond, Peter. (2016). "Hill and Mountain", in: Carole Hough (ed), The Oxford Handbook of Names and Naming, pp. 115-124. United Kingdom : Oxford University Press.

Gonda, J. (1973). Sanskrit in Indonesia. New Delhi: International Academy of Indian Culture.

Hoed, B. H. (2011). Semiotik \& Dinamika Sosial Budaya. Jakarta: Komunitas Bambu.

Hoed, Benny H. (2001). Dari Logika Tuyul ke Erotisme. Magelang: Indonesia Tera.

Hough, Carole. (2016). The Oxford Handbook of Names and Naming. United Kongdom: Oxford University Press.

Lauder, F. Allan dan Lauder, R.M.T. Multamia. (2015). "Ubiquitous Place Names : Standardization and Study in 
Indonesia," dalam: Moeimam and Engelenhoven (eds), Wacana Jurnal Ilmu Pengetahuan Budaya Vol. 16 No. 2, hlm. 383-410. University of Indonesia: Faculty of Humanities.

Martha, Sukendra. (2007). "Peran Toponimi untuk Kepentingan Sosial, Ekonomi, dan Budaya," dalam Widodo E. Santoso dan Titiek Suparwati (eds), Risalah Workshop Toponimi: Kebijakan dan Implementasi Pembakuan Nama Rupabumi, hlm. 918. Jakarta: Pusat Pemetaan Dasar Rupabumi dan Tata Ruang Bakosurtanal.

Nöth, Winfried. (1999). "Pierce", dalam Handbook of Semiotics. Bloomington: Indiana University Press.

Permana, E.C.R. (2016). Kamus Istilah Arkeologi Cagar Budaya. Jakarta: Wedatama Widya Sastra.

Poerwadarminta, S.J.W. (1939). Baoesastra Djawa. Batavia: Ketjap Ing Pangetjapan Wolters Uitgevers Maatscha Ppij Groningen.

Rais, J., Lauder, M., Sudjiman, P., Ayatrohaedi, Sulistiyo, B., Wiryaningsih, A., Suparwati, T., dan Santoso, E. W. (2008). Toponimi Indonesia: Sejarah Budaya Bangsa yang Panjang dari

Permukiman Manusia dan Tertib Administrasi. Jakarta : PT. Pradnya Paramita.

Suratminto, L. (2007). "Teks Pada Batu Nisan Baron Van Imhoff Dilihat Melalui Analisis Semiosis Model Peirce Dan Danesi-Perron". Depok: Fakultas Imu Pengetahuan Budaya Universitas Indonesia.

Tim Penyusun Kamus Pusat Pembinaan dan Pengembangan Bahasa. (1990). Kamus Besar Bahasa Indonesia.
Jakarta: Departemen Pendidikan dan Kebudayaan.

Utomo, S. (2009). Kamus Lengkap JawaIndonesia. Yogyakarta. Kanisius.

Wojowasito. (1977). Kamus KawiIndonesia. Bandung : CV. Pengarang.

Yule, George. (2006). The Study of Language. UK : Cambridge University Press. 